\title{
The Transition from Feudalism to Capitalism and the Problem of Temporalization-on the 100th Anniversary of Witold Kula's Birth
}

\begin{abstract}
The Marxist social historian Witold Kula (1916-1988) demonstrated more thoroughly than any other scholar that the changes in the conditions of agricultural production also changed 'historical time'. Kula describes the period between 1770 and 1880 as a transition zone in which an acceleration of historical time occurs because it does not yet correspond to experience. The historical process bursts open the old European continuum of experience, and the first category in which the temporal difference between experience and expectation is conceptualized is the term 'progress'. He does not, however, consider this transition from the feudal to the capitalist movement pattern to be fluent. According to Kula, capitalism in most countries did not develop out of the feudal economy or as a consequence of gradual changes within the system, but developed above it as an autonomous system in the form of a superstructure.
\end{abstract}

\section{Stability through cyclicity}

In the last century, the transition from feudalism to capitalism has been the subject of a number of debates on both sides of the Atlantic. This was particularly the case in the 60s and 70s when the topic served to position economic history firmly within the historical sciences and philosophy. As part of this quest for the realignment of economic history as a field of research, some historians favorably disposed to philosophy were resolute in their insistence on the philosophical roots of the economic sciences, in an endeavor to secure a firm place for philosophy-or, to be more precise, for Marx's philosophical categories-within historical studies (see as an example: Kittsteiner 1980). Those historians, on the other hand, who favored researching socio-economic structures endeavored to establish the economic sciences as a subdivision of social history, and to strip them of any budding historical-philosophical tendencies (cf. Wehler 1973).

If one were to ask today any scholar of modern history interested or involved in these past debates whether he or she had been aware of an Eastern European position on this discussion, the answer would most certainly be in the affirma-

Agnieszka Pufelska, Universität Potsdam (UP)

Ә OpenAccess. () 2018 Agnieszka Pufelska, published by De Gruyter. (cc))BY-NC-ND This work is licensed under the Creative Commons Attribution-NonCommercial-NoDerivatives 4.0 License. 
tive (in the case of Marx readers, not without a degree of cheer), and Witold Kula would be named. His books, and first and foremost his An Economic Theory of the Feudal System, were read, valued and criticized by both camps. Whereas social historians were interested in Kula's analyses of the feudal social order, their adversaries concentrated mainly on his universal historical model of economic theory, or his dynamic functional model of the feudal economy.

But who was this Polish scholar, whose feudalism theory won recognition far beyond the borders of Europe? Witold Kula was born in Warsaw in 1916 into a Protestant family of German descent. After graduating in Economics and History from the University of Warsaw, he lectured at a private university, where he defended his doctoral thesis in 1939. During the Second World War, he was a member of the Home Army and was taken prisoner by the Germans. In 1945 he returned to Poland and immediately took up his academic career. He obtained his post-doctoral degree (Habilitation) from the University of Łódź in 1947, following which he received a scholarship for two years in Paris, where he was influenced by the Annales school. Shortly after his return, he was appointed Professor at Warsaw University where he held the Chair for Economic History until 1975. By then seriously ill, he had to give up his academic teaching at the age of just 60. Witold Kula died in Warsaw on 12 February 1988.

Kula's academic work consists mainly of studies on Polish economic history, but he also worked intensively on the methodological and theoretical problems of the historical sciences. His most well known work in this field is the book that appeared in 1963 entitled The Problems and Methods of Economic History. It is in this almost 800-page work of a universalist nature that Kula most clearly formulates his methodology. He accepts, not only in a formal sense, the progressive tenets of Marxist methodology and assumes the position of Marxist periodization that is based on the development of socio-economic formations. "For the Marxists," Kula writes, "the periodisation of history is, therefore, equally a synthesis of historical cognition and a tool thereof" (Kula 1963, p. 175).

One of the central problems in Kula's work is the question of synthesis in economic history. He emphasizes the essential differences between the courses of many economic processes in diverse social orders and draws attention to the limited comparability of these processes. The disparity between the socioeconomic systems necessitates a different methodological approach that, in turn, should result in a synthesis determined by time and space. In the most renowned of his works, the above-mentioned An Economic Theory of the Feudal System, Kula uses the Polish transition from feudalism to capitalism to describe how this research method could be applied. The book was first published in 1962 but only became known in Western Europe in the 1970s when it was translated, 
first into French and then into English. What, in Kula's opinion, were the conditions that such a theory should fulfill?

We can say that the task of every economic theory of a system consists in formulating the laws governing the volume of the economic surplus and its utilization and that these problems have to be explained in the short-term and in the long-term. (Kula 1976, p. 27)

However, in order to speak of the conclusion or the climax of an economic theory, Kula argues that it has to be able to explain the transformation of one given system into another (Kula 1976, p. 27).

Clearly, Kula attempts in his feudalism research to investigate what Marx did not achieve-at least not as an independent analysis-and that he only analyzed based on what was apparent to him from the viewpoint of the emerging capitalist mode of production. It is not in vain that Kula's temporal framework of the 16th to the 19th centuries covers Marx's history of 'primitive accumulation', i.e. the history of the separation of the direct producers from their means of production and nourishment, which was for Marx the core of the history of the transition from feudalism to capitalism. ${ }^{1}$

In Kula's historical reconstruction, the first signs of economic decline in Poland are evident in the 16th century, otherwise seen as the 'golden century', characterized by economic, cultural and political development. Kula sees the causes for this in the strengthening of serfdom and the corresponding increase in the power of the nobility. Their high standard of living was supported by an economy that guaranteed Poland the position of a European granary and enabled the aristocracy to import luxury goods from abroad. Whilst the aristocracy thus had close connections with the international market, also through the 'term of trade', the peasants remained excluded and increasingly tied to feudal dependencies. This process reached its climax in the so-called 'crisis of the 17th century', which was heightened in Poland by external influences such as the wars against the Cossacks and Sweden.

The country fell into a state of economic backwardness characterized by a concentration of land ownership in the form of estates ruled by the wealthy nobility. All types of feudal dues, both ordinary and extraordinary, were fully developed and the peasants' obligations had become very oppressive. An analysis of surviving invoices showing income and expenditure of several feudal estates led Kula to conclude that, when considering only monetary expenditure and income,

1 Marx writes: "The economic structure of capitalist society has grown out of the economic structure of feudal society. The dissolution of the latter set free the elements of the former." (Marx 1972, p. 743.) 
these estates must have produced a substantial yield, but that if the material effort (not measured in terms of money) in the form of corvées obligations was calculated into this, the result would be a large deficit: "The average peasant does not take into account the cost of family labor nor interest on capital because he has not knowledge of such categories and does not know how to make accurate calculations" (Kula 1976, p. 41). The farms were inefficient without knowing it.

In Kula's opinion, this is not simply an invoicing problem: he derives from it a 'two-sector system', i.e. the side-by-side existence of a monetary and a natural economy. The peasants who belonged to the nobility had to pay them dues, mostly as payment in kind, but they were also obliged to perform certain services for the nobility. The activities of the noble landowners on the other hand, were oriented around a market where they exchanged the peasants' dues for money, such that their calculations were focused on increasing income from the manorial estate. Under manorial rule, the production of commodities was successfully developed: the ruling class used their privileges to secure cheap labor power, raw materials and advantages in selling their goods. The feudal lords were thus able to make good use of the economic advantages of peasant agriculture; that is, of low labor costs, high labor intensity and low unproductive expenses. The lower the intensity and productivity of agricultural labor, the more the manorial lords attempted to reduce production costs by increasing feudal labor obligations. Feudal labor service reduced production and transport costs and secured the continued existence of the manorial estate even when market prices for grain and other products were low. Even more to the point, Kula argues that the income from grain was more dependent on the harvest yield than on the actual price, because when harvests were poor the price increase only offset to a limited extent the reduced amount of saleable goods. Lords and peasants both benefited when they sold larger amounts of grain at low prices than when prices increased and they were only able to sell less:

Under capitalism, an increase in prices is the stimulus that sets reserves in motion and brings about an increase in national income. In the feudal system, on the other hand, a reduction in the social income leads to an increase in price [generally due to non-economic factors such as failed harvests or wars]. (Kula 1976, p. 110)

The material situation of a manorial estate and the serfs who lived there was thus determined to a greater extent by the harvest than by price fluctuations (Kula 1976, p. 56).

Bad harvests also had a negative effect on town-dwellers as they were then forced to pay higher prices for food. In order to meet their needs for essential goods, they had to do without other things, and the demand for the products 
and services of tradesmen sank accordingly. For this reason, and because the peasants were not able to buy as much, trade and commerce stagnated. Hardship abated when harvests improved. The prices of agricultural products went down, the peasants' income increased, and the tradesmen in the towns were able to sell more of their products. The economic upturn continued until poor harvests again brought crisis to the towns and country.

"The peasant," Marcus Sandl writes in his essay on the concept of circulation and the cameral sciences knowledge system in the 18th century, "did not have sufficient means to control nature and thus was not able to autonomously shape production processes, but was obliged to rely on 'means with which he artificially supported nature for economic purposes.' In this sense, there are almost as many agricultural times as there were manorial estates" (Sandl 2002, p. 69). Translated into temporal categories, this might mean: up to and even beyond the mid-18th century, the alternating rhythm of 'good' and 'bad' years shapes a concept of an oscillating history with a re-occurrence of the same or similar situations. The long-term dynamics are subject to recurring short-term setbacks, but people have no experience of any tendency that would indicate improvement or continuous progress in their life situation as a whole. There is no overall historical dynamic or development that can impress itself on experience. Expectations are determined by previous experiences. In 1797 Kant noted that most people lived in a system of the 'abderitism of history'; things do not move forwards, nor do they move backwards-the ordinary run of things is marked by a haphazard up and down (Kant 1995, p. 99).

\section{The peasants begin to move}

Despite the feudal balance that, although subject to marked secular fluctuations, stabilizes time and again on a barely altered level, Kula sees in feudalism (and here he is closely following Labrousse's crisis theory) a general weakness and proneness to crisis. ${ }^{2}$ Insofar as feudal society remains within the limits of an exchange of agricultural sector surpluses, its development is not compromisedprovided these surpluses are indeed generated and exchanged. It is only when

2 The French economic historian Ernest Labrousse postulated, primarily for the 18th century, a link between high prices of grain used for bread and market stagnation in the manufacturing, pre-industrial sector: "La crise cyclique de sous-production agricole ne reste pas agricole dans ses conséquences. Elle gagne toute la vie industrielle. La sous-production agricole déclanche une crise de sousconsommation industrielle, de surproduction industrielle relative.” (Labrousse 1933, p. 528) 
this system, by reason of its immanent long-term dynamics, reaches its productivity limits that its instability becomes apparent. And it is precisely this problem that Kula observes in Poland from the middle of the 18th century onwards, when the grain prices and ground rents in Central Europe began to rise and greater profits were zealously generated. The burden on the peasants was too large and far exceeded their production potential. This method of production, determined as it was by feudal appropriation, reaches an impasse. As does Marx, Kula sees the changes in the dominant form of appropriation of the surplus product as marking the transition from feudalism to capitalism.

In Kula's feudalism model, however, the loss of efficiency experienced by the farms in the 18th century is by no means unexpected or determined solely by external factors. On the contrary, he sees this as something that had persistently accompanied the feudal manorial economy and which, as such, was testimony to its instability: the short-term crises of feudalism that caused recurring slumps in long-term dynamics are, for Kula, an inner component of the feudal system, and are also transformed with the system. In a polemical attack on Fernand Braudel's concept of crisis, Kula asks: "Nobody doubts for a moment that a general crisis is also a direct crisis of history. But is all this so new? Is crisis not a permanent feature? Has it not always existed?” (Kula 1983, p. 236)

He expounds the transforming proneness to crisis of feudal manorial society in his theory on the lord-peasant-struggle in Poland and, cum grano salis, in Prussia between the 16th and 18th centuries. Kula assumes that the lord of the manor had to exert pressure on the peasants-who dominated the production process-in order to generate the surplus that determined his own level of existence. The reason for this, Kula argues, was the permanent resistance of the peasants in the form of sabotage or flight. The lords' greatest losses in collecting the surplus were incurred, however, through the peasants' contact with the market. There was a bitter struggle as to the "market quota" between the peasant, who was obliged to pay his dues in produce, and his lord. Whereas the peasant attempted to sell a part of the surplus remaining over and above what he required for subsistence, the lord strove equally resolutely to sever all the peasants' market relations. He attempted to achieve this by exchanging the peasants' money for goods produced on his own manor as well as by reducing the size of the farms. From the 16th century onwards, the Polish peasants who were obliged to pay rent to their lords in money and in natura were able to consume or to market with profit their own harvest surplus. In order to stop the flow of money from the estate and thus to compensate for the loss of natural produce sold by the peasants, the lords began to create their own markets. Even though there were new developments aimed at increasing the monetary income through direct and indirect monetization of the peasants' produce, it remained the goal of 
the rulers to ensure that buying and selling continued to be in their hands. Monetary revenue came primarily from the sale of the farmers' own produce, such as vodka. It should be borne in mind, however, that the peasants were obliged to source their vodka from their lords. To illustrate this, Kula quotes a letter from Prince Czartoryski who complained in about 1780 that, without propination, he was unable to obtain a regular monetary income and that, particularly in the 'bad' years, the distilleries had taken on the function of mints (Kula 1976, p. 137). This letter shows more than simply the lords' share of responsibility in securing the Polish predilection for vodka. Above all, it draws attention to the peasants' money reserves, and thus also to their market connections, which persisted despite the bad years and the lords' attempts to prevent those connections.

Another method employed by the lords to isolate peasants from the market was the above-mentioned reduction in the size of the farms. The nobility clearly had no interest in the ruin of their subjects. But, the smaller the average farm, the less use the peasant could draw from favorable market conditions. If the good harvest years were used as a measure of this size, the number of bad years increased for the peasant, because even slight harvest fluctuations meant that his agricultural reproduction was no longer secure. Also, the lords of the manor had to provide material support for the peasants to the extent that they were unable to produce a surplus themselves. In the long term, this conflict pushed the feudal system to its limits. The efficiency of manorial estates sank continuously from the 16th to the 18th century, resulting in rising indebtedness. The estates, in turn, were unable to bear the burden of the amassed debts of their owners.

The capitalization of agriculture slowly began to take over towards the end of the 18th century. The Polish nobility chose to follow the 'Prussian path' and gradually adopted the 'rent system', the consequence of which was the infamous 'struggle for rent'. The lords fought to raise the rent so as to be able to assert themselves in competition with their peers. For the peasants, on the other hand, it was important to be able to appropriate for themselves a part of the surplus they produced. The only means they had of doing this was through lower rents, resistance, increase in the area of land they cultivated or greater labor productivity. Peasant families also strove to use other means to make up for the income deficit which arose from their agricultural labor. They generally supplemented their income by work in the various trades or other non-agricultural sectors; this, in turn, tied them more and more closely to the market. The peasants had spread their labor power as 'entrepreneurs' across several fields of work that promised cash income, and this 'obligation' to become market players doubtless widened their action radius. Over and beyond this, they developed 
their own strategies to avoid being subjected entirely to the constraints of the market, or of their rulers, by pursuing mixed economic activities and allowing themselves some flexibility. Farms now became businesses geared towards achieving an economic balance, while the lords of the manor became capitalist landowners who understood-as Kula noted ironically-that 'money makes money', and that land is a commodity (Kula 1955, p. 34).

With these changes in the conditions of agricultural production, 'historical time' also changed; that is to say there was a change in the 'tempus' of social reproduction, and the income of the manorial estates began to depend on investments and market prices rather than on weather conditions:

Finally, we might risk a generalization: in precapitalist societies many economic indices are subject to great fluctuations in the short run and only to very slow change in the direction of the trend; in industrial societies, however, the range of short-run fluctuations is reduced, but the trend of changes in direction is accelerated and becomes more pronounced (for example, the demographic coefficients, returns to land etc.). (Kula 1976, p. 183)

The entire society becomes an accelerated society. The period between 1770 and 1880 can thus be considered a transition zone in which an acceleration of historical time occurs because it does not yet correspond to experience. The historical process bursts open the old European continuum of experience, and the first category in which the temporal difference between experience and expectation is conceptualized is the term 'progress'. ${ }^{3}$

\section{Back to Kula}

Kula does not, however, consider this transition from the feudal to the capitalist movement pattern to be fluent. "There is no doubt," he states, "that certain elements change rapidly, others slowly or very slowly, and certain elements can be

3 'Experience' and 'expectation' are two central historical conceptual categories for Reinhart Koselleck. Similarly to Kula, he sees what is new in modernity as the increasing gap between experience and expectation. He argues (though without giving examples) that the reason for this change is the transition from a circular to a linear view of history: "The peasant world, which two hundred years ago comprised up to 80 percent of all persons in many parts of Europe, lived with the cycle of nature. Excepting the structure of social organization, fluctuations in market conditions, especially long-distance trade in agricultural products, and monetary fluctuations, the everyday world was marked by whatever nature had to offer. [...] Technical developments, which did exist, took so long to become established that they did not cause a rupture in the pattern of life.” (Koselleck 1989, p. 360) 
regarded as constant” (Kula 1976, p. 182). The emphasis on the non-contemporaneousness of change is related to Kula's thesis on the various adaption options of the respective systems to new conditions. This, in turn, testifies to the 'elasticity' of the feudal system, which allows it to retain its character although changes have taken place. Kula divides the adaptation processes to which the feudal system is subject into avoidable and unavoidable changes. He sees the latter as being of a cumulative nature, whereby they triggered the transition of one structure into another or stretched the feudal system beyond its limits, only to replace the old structure by a new one. In other words, in long-term dynamics, Kula differentiates between elements that operate 'periodically' or 'continuously', and that in their cumulative effect have led to structural transformations from the mid-18th century onwards (Kula 1976, p. 118).

Following this line of argumentation, then, capitalism in Poland (as in most other countries) did not develop out of the feudal economy or as a consequence of gradual changes within the system, but developed above it as an autonomous system in the form of a superstructure. "Feudalism was pregnant with capitalism,” Kula writes at one point (Kula 1983, p. 242). With the exception of England, the industrialization of European culture resulted from the 'pressure' of an already existent capitalism:

Capitalism only emerged spontaneously once in the history of the world [: in England]. The same is true of socialism. But there are various feudalisms around the world. They have come about independently of one another in diverse societies and epochs. (Kula 1983, pp. 68-69).

This thought is central to Kula's development theory. He sees a twofold course for the historical cultural process: it develops in one particular direction and also in several different directions simultaneously. He calls this cultural theory a 'dialectic theory of unity and diversity for the course of time and for change'. Contrary to the course of time, change never takes place in one direction only-a position that contradicts those of Adam Smith and even Karl Marx. For this reason, Kula also suggests that we should assume the multilinearity of the historical process and regard its dynamics as a wide range of comparable changes:

It is only possible to develop an overall theory of feudalism if analyses of feudalism in Japan, China or India are consulted [...] Only in the light of such comparisons can we determine what may be generally valid or meaningful for our [European] feudalism. (Kula 1958, p. 35)

As a reminder: Kula made this call for comparative global history at the end of the 1950s, long before Jürgen Osterhammel's groundbreaking work on universal 
history. The thesis that a number of trade capitalisms blossomed in various parts of the world in the developing global economy of the 17th and early 18th centuries runs through all of Kula's economic analyses; capitalism functioned from the start as a global economy-and globalization is thus a process that has been in progress for centuries. Kula's development theory of unity and diversity presupposes the global connectivity but concurrent fragmentation of trade, politics and cultures. This principle was the reason for his appeal to historiography:

If the fundamental problem of our epoch is the unity of the planet in the face of industrial civilisation, then it may be the duty of contemporary historiography to ask of the past what leads us to this unity. Let us not hesitate, let us contemplate the long periods of time and large spaces. (Kula 1983, p. 255)

In his plea for the 'great narration', Kula also attempts to point out the dangers of using the concept of totality. Criticism of teleological historical concepts à la Hegel plays a large part in Kula's theory on the course of the historical process. Extremely well-read in German philosophy of history, he now no longer assumes that a perfect, but rather an imperfect 'whole' is mediated. For Kula, this imperfection results from the non-availability of history, and he thus places people, who consciously act in and endure history, in a process of which they are not conscious-one which results from their actions, but which is outside of their control. Yet his criticism of purposive conceptions of development is in no way contradictory to his conviction that the historical process takes a directional course. ${ }^{4}$ He speaks of a "directional development without a teleological vision of an earthly paradise” (Kula 1958, pp. 215-216). Such a statement from the mouth of a professor living in the 'best of all communisms' was not a matter of course. For Kula, Soviet-style Communism was an integrative component of the prevailing capitalism.

To sum up: Kula sees a strong accumulation of century-long tendencies that appeared insignificant as long as the feudal system remained intact and func-

4 Heinz-Dieter Kittsteiner, a cultural historian who died in 2008, was of a similar view. Following Kant and Marx, he assumes that people can extend their idea, but not their actions, to the whole: "Man does not readily 'make' his history, history evolves-in the context of society, admittedly-unconsciously, so to speak, when uncoordinated actions encounter one another." (Kittsteiner 1997, p. 83) Unlike Kula, Kittstein has a distinct historical-philosophical approach. He looks for non-teleological options in a philosophy of history that maintains insight into the non-availability of events. To this end, he strives to subject certain key categories of the history of philosophy to a rational analysis; his last book, Die Stabilisierungsmoderne: Deutschland und Europa 1618-1715, represents such an endeavor. For an in-depth analysis, see: Pufelska 2010, pp. 173-195. 
tional, but which played a decisive role in the period of its transition to capitalism. These include the advance of industrialization, cuts in interest rates for loans, increasing mobility among the population, and the peasants' attempts at market involvement. Because the resulting changes arose from all previous experience, they gave reason to hope for continuous progress: and this hope was great, for "if a structure is destroyed, nobody is in a position to predict what the new structure which arises from the ruins of the old will look like" (Kula 1983, p. 296).

\section{Bibliography}

Kant, Immanuel (1995): “Der Streit der Fakultäten”. In: Toman, Rolf (Ed.): Kants Werke in 6 Bänden. Vol. 6. Köln: Könemann.

Kittsteiner, Heinz-Dieter (1980): Naturabsicht und Unsichtbare Hand. Zur Kritik des geschichtsphilosophischen Denkens. Frankfurt am Main: Ullstein.

Kittsteiner, Heinz-Dieter (1997): “Aufklärung durch Geschichtswissenschaft?” In: Enskat, Rainer (Ed.): Wissenschaft und Aufklärung. Opladen: VS Verlag für Sozialwissenschaften, pp. $75-95$.

Koselleck, Reinhart (1989): Vergangene Zukunft. Zur Semantik geschichtlicher Zeiten. Frankfurt am Main: Suhrkamp.

Kula, Witold (1955): Ksztattowanie się kapitalizmu w Polsce. Warszawa: Państwowe Wydawnictwo Naukowe.

Kula, Witold (1958): Rozważania o historii. Warszawa: Państwowe Wydawnictwo Naukowe.

Kula, Witold (1963): Problemy i metody historii gospodarczej. Warszawa: Państwowe Wydawnictwo Naukowe.

Kula, Witold (1976): An Economic Theory of the Feudal System. Towards a model of the Polish Economy 1500-1800. London: NLB.

Kula, Witold (1983): Historia zacofanie rozwój. Warszawa: Czytelnik.

Marx, Karl (1972): “Das Kapital: Kritik der politischen Ökonomie”. In: Marx, Karl / Engels, Friedrich: Werke (MEW). Vol. 23. Institut für Marxismus-Leninismus beim ZK und SED (Ed.), Berlin: Dietz.

Labrousse, Ernest (1933): Esquisse du mouvement des prix et des revenus en France au XVIIIe siècle. Paris: Dalloz.

Pufelska, Agnieszka (2010): “Kittsteiners 'evolutive Moderne' als eine geschichtsphilosophisch angeleitete Kulturgeschichte”. In: D’Aprile, Iwan-Michelangelo / Mak, Ricardo K. S. (Eds.): Aufklärung-Evolution-Globalgeschichte. Hannover: Wehrhahn, pp. 173-195.

Sandl, Marcus (2002): "Zirkulationsbegriff, kameralwissenschaftliche Wissensordnung und das disziplinengeschichtliche Gedächtnis der ökonomischen Wissenschaften”. In: Schmidt, Harald / Sandl, Marcus (Eds.): Gedächtnis und Zirkulation. Der Diskurs des Kreislaufs im 18. und frühen 19. Jahrhundert. Göttingen: Vandenhoeck et Ruprecht, pp. $65-81$.

Wehler, Hans-Ulrich (Ed.) (1973): Geschichte und Ökonomie. Köln: Kiepenheuer \& Witsch. 
